\title{
Chylous Clot Removal Using Morecellator: A Novel Method
}

\author{
Ankur Bansal*, Ankur Jhanwar, Gaurav Prakash and Satyanarayan Sankhwar \\ King George Medical University, Uttar Pradesh, India
}

Submission: December 15, 2016; Published: February 06, 2017

*Corresponding author: Dr Ankur Bansal, Senior Resident Department of Urology, King George Medical College, India, Tel: 8853807160

Email: ankurbansaldmc@gmail.com

\begin{abstract}
We report a novel method of chylous clot removal using morcellator where otherconventional methods fail. A 22 years male with recurrent chyluria presented in acute urinaryretention. Clot evacuation using Toomey syringe, ellik evacuator and suction bridge havefailed. Based on our use of morcellator (versa cut tissue morcellator, lumenis) during HoLeP procedure, we applied this morcellator to morcellate large and tenacious chylous clot. Wesuccessfully removed the clot using morcellator with suction (versa cut tissue morcellator, lumenis) used for morcellating prostate adenoma tissue in holmium laser enucleation of prostate (HoLeP).
\end{abstract}

Keywords: Chylous clot; Morcellator chyluria; Lumenis; Ellik evacuator; Toomey syringe; Alteplase; Hematuria; Bladder injury

\section{Introduction}

Chyluria is passage of chyle in the urine due to abnormal communication between intestinal lymphatics and urinary tract causing intermittent discharge of chyle from intestinal lymphatic into renal pelvis. Common urological presentation is in the form of passage of milky-white urine, chylo-hematuria and rarely, acute urinary retention due to clots. Methods of clot evacuation include Ellik evacuator, Toomey syringe and suction bridge [1]. Rarely, open cystotomy is required for patients where conventional methods fail. We report a novel method of clot evacuation using morcellator thus avoiding open cystotomy.

\section{Case Report}

A 22-year old male, a known case of recurrent chyluria, presented with acute urinary retention. Abdominal ultra-sound revealed a large clot in urinary bladder with normal upper tracts (Figure 1). Emergent cystoscopic examination revealed a large and tenacious chylousclot in the bladder (figure 2) and efflux of chyle from the left ureteric orifice with clear-urinary efflux from the right side. Clot removal was attempted with Ellik evacuator, Toomey syringe and mechanical suction using suction bridge. However, these procedures failed to remove clots due to the elasticity and large size of clot. Morcellation and suction (VersaCut tissue morcellator, Lumenis) was performed with morcellator used for morcellating prostatic adenoma tissue in holmium laser enucleation of prostate (HoLEP) procedure to evacuate the clot (Figure 3). The integrity of the urinary bladder was ensured. Post procedure, bladder irrigation through 22-Fr
Foley catheter (triway) was initiated and post-operative period was uneventful. Foley catheter was removed after 48-hrs. Later the patient was managed with sclera therapy using $0.2 \%$ povidine iodine on the left side [2].

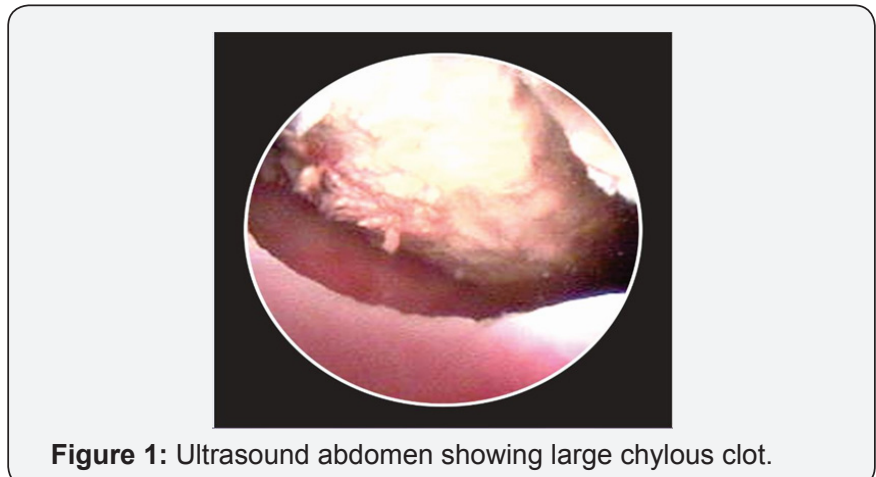

Figure 1: Ultrasound abdomen showing large chylous clot.

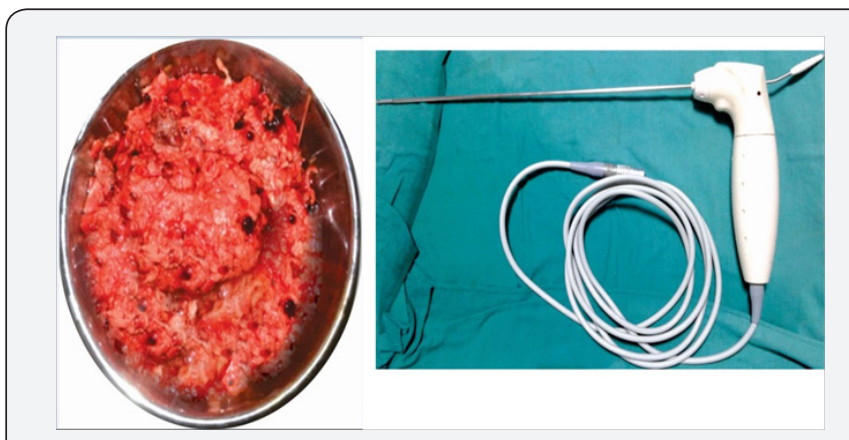

Figure 2: Cystoscopic view of large chylous clot. 


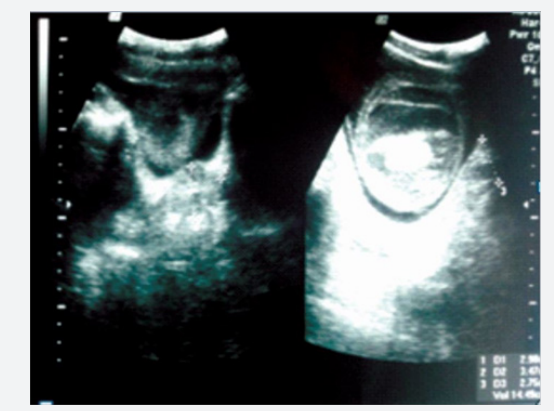

Figure 3: Morcellated chylous clot and Morcellator.

\section{Discussion}

Large blood and chylous clots can cause urinary retention. In most cases, clot evacuation with Ellik evacuator or Toomey syringe is effective. But, sometimes pressures generated by the same methods are not enough to remove large and tenacious clot and may cause bladder injury. To avoid open cystotomy for the removal of large and tenacious clots, various non-surgical treatments are described. Bo, et al. [3] in their study mentioned the use of $40,000 \mathrm{U}$ of chymotrypsin in $50 \mathrm{ml}$ of $5 \%$ sodium bicarbonate for blood clot removal [3]. Ritch, et al. [4] describe the use of alteplase (tissue plasminogen activator) for dissolving blood clots [4]. Goel, et al. [5] described the use of mechanical suction for safe removal of large and tenacious clots from the urinary bladder [5]. But the effectiveness of these methods for removing chylous clot is not known. Minimally-invasive method of chylous clot removal has not been mentioned in literature due to rarity of this disease in western population. Morcellation of prostatic adenoma is needed after trans-urethral HoLeP. It has a combination of tissue morcellator and suction. We used this method for clot removal in our patient thus avoiding open cystotomy. Although, gaining popularity, HoLEP is not available in all urology centers. We suggest the use of morcellator (versacut tissue morcellator) in patients with clot retention where other methods fail. As morcellation is done under vision there are fewer chances of complications like perforation and hematuria. It is also faster and more effective. Although, we have used this method for removal of chylous clots but morcellator should be effective for removal of large blood clots also. To the best of our knowledge this is the only report in the literature where large and tenacious chylous clots have been removed using morcellator with suction (versa cut tissue morcellator) (Figure 3).

\section{Conclusion}

Clot evacuation using morcellator is safe and feasible approach and should be kept in mind where other methods have failed. However, it can be used only by surgeons who have experience with this method.

\section{References}

1. Goel A, Dalela D (2015) Mechanical suction for clot evacuation: experience with "suction bridge" for safe and effective clot removal. Int Urol Nephrol 47(5): 723-726.

2. Goel S, Mandhani A, Srivastava A, Kapoor R, Gogoi S, et al. (2004) Is povidine iodine an alternative to silver nitrate for renal pelvic instillation sclerotherapy inchyluria? BJU int 94(7): 1082-1085.

3. Bo J, Yangyang Y, Jiayuan L, Siwen D, Yong C, et al. (2014) Evaluation of bladder clots using a non-surgical treatment. Urology 83(2): 498-499.

4. Ritch CR, Ordonez MA, Okhunov Z, Araujo J, Walsh R, et al. (2009) Pilot study of Alteplase (tissue plasminogen activator) for treatment of urinary clot retention in an in-vitro model. J Endourol 23(8): 13531357.

5. Goel A, Sengottayan VK, Dwivedi AK (2011) Mechanical suction: an effective and safe method to remove large and tenacious clots from the urinary bladder. Urology 77(2): 494-496.

This work is licensed under Creative Commons Attribution 4.0 License

\section{Your next submission with Juniper Publishers} will reach you the below assets

- Quality Editorial service

- Swift Peer Review

- Reprints availability

- E-prints Service

- Manuscript Podcast for convenient understanding

- Global attainment for your research

- Manuscript accessibility in different formats

( Pdf, E-pub, Full Text, Audio)

- Unceasing customer service

Track the below URL for one-step submission https://juniperpublishers.com/online-submission.php 